\title{
Enzyme activities and growth promotion of spinach by indole-3-acetic acid-producing rhizobacteria
}

\author{
R. Çakmakçi, M. Erat, B. Oral, Ü. Erdogan \& F. Șahin
}

To cite this article: R. Çakmakçi, M. Erat, B. Oral, Ü. Erdogan \& F. Șahin (2009)

Enzyme activities and growth promotion of spinach by indole-3-acetic acid-producing rhizobacteria, The Journal of Horticultural Science and Biotechnology, 84:4, 375-380, DOI: 10.1080/14620316.2009.11512535

To link to this article: http://dx.doi.org/10.1080/14620316.2009.11512535

曲 Published online: 07 Nov 2015.

Submit your article to this journal \ulcorner

山 Article views: 7

View related articles $\sqsubset$

Citing articles: 3 View citing articles 


\title{
Enzyme activities and growth promotion of spinach by indole-3-acetic acid-producing rhizobacteria
}

\author{
By R. ÇAKMAKÇI ${ }^{1 *}$, M. ERAT ${ }^{2,3}$, B. ORAL ${ }^{3}$, Ü. ERDOGAN $^{4}$ and F. ȘAHIN ${ }^{5}$ \\ ${ }^{1}$ Department of Agronomy, Faculty of Agriculture, Atatürk University, 25240 Erzurum, Turkey \\ ${ }^{2}$ Erzurum Vocational Training School, Atatürk University, 25240 Erzurum, Turkey \\ ${ }^{3}$ Biotechnology Application and Research Center, Atatürk University, 25240 Erzurum, Turkey \\ ${ }^{4}$ Technical Vocational School Îspir, Atatürk University, 25900 Erzurum, Turkey \\ ${ }^{5}$ Department of Genetic and Bioengineering, Faculty of Engineering and Architecture, Yeditepe \\ University, Kayısdagi, 34755 Istanbul, Turkey
}

(e-mail: rcakmak@atauni.edu.tr)

(Accepted 17 January 2009)

\begin{abstract}
SUMMARY
The objective of this study was to evaluate the effects of twelve plant growth-promoting rhizobacteria (PGPR; Bacillus mycoides FD07, B. sphaericus RC12, B. pumilus RC19, B. cereus RC18, Variovorax paradoxus RC21, Paenibacillus polymyxa RC35, Pseudomonas putida RC06, B. megaterium RC07, B. megaterium M-3, B. licheniformis RC08, B. subtilis RC11, and B. subtilis OSU-142) used as biofertilisers, on various enzyme activities [glucose-6-phosphate dehydrogenase (G6PD); 6-phosphogluconate dehydrogenase (6PGD); glutathione reductase (GR); and glutathione S-transferase (GST)] and on seedling growth in spinach (Spinacia oleracea L.). Enhanced plant growth could result from rhizobacterial production of indole-3-acetic acid (IAA). The highest IAA-producing rhizobacteria (RC35 and RC06) produced the highest root and shoot weights. PGPR improved N and P nutrition in spinach, and therefore stimulated plant growth and key enzyme activities. The responses to inoculation, compared to uninoculated control plants, were: $-1.9 \%$ to $+36.4 \%$ for shoot fresh weights (FWs), $-5.5 \%$ to $+30.1 \%$ for root FWs, $-3.5 \%$ to $+29.8 \%$ for shoot dry weights (DWs), $-3.8 \%$ to $+38.5 \%$ for root DWs, and $-5.9 \%$ to $+30.1 \%$ for leaf areas. Plant growth responses were variable and dependent on the inoculant strain used, as well as on the enzyme activity and growth parameter being evaluated. Close correlations between plant shoot growth, PGPR inoculation, and G6PD $\left(r=0.28^{*}\right), 6$ PGD $(r$ $\left.=0.55^{* *}\right)$, GR $\left(r=0.73^{* *}\right)$, and GST $(r=0.64 * *)$ enzyme activities in spinach have been demonstrated.
\end{abstract}

$\mathbf{N}$ trogen $(\mathrm{N})$ and phosphorus $(\mathrm{P})$ are essential for plant growth and development, and often limit productivity. Increments in mineral $\mathrm{N}$ rates caused an increase in the $\mathrm{NO}_{3}{ }^{-}$content of spinach (Gülser, 2005), and $\mathrm{NO}_{3}^{-}$accumulation warrants serious attention because of its hazardous effects on human health. Plant growth-promoting rhizobacteria (PGPR) have been considered as a possible alternative to inorganic fertiliser for promoting plant growth. PGPR may affect plant growth directly by synthesising phytohormones and vitamins, through $\mathrm{N}$ fixation for plant use, by improvements in nutrient uptake, by enhanced stress resistance, and/or by the solubilisation of inorganic phosphate (Dobbelaere et al., 2003).

These physiological changes are linked to increases in various enzyme activities, and the mRNAs and protein levels required for $\mathrm{NO}_{3}^{-}$assimilation into amino acids. Nitrogen assimilation in plants consists of three processes. First, $\mathrm{NO}_{3}^{-}$is reduced to $\mathrm{NO}_{2}^{-}$by nitrate reductase. Second is the reduction of $\mathrm{NO}_{2}^{-}$to $\mathrm{NH}_{4}^{+}$by nitrite reductase. Third, $\mathrm{NH}_{4}{ }^{+}$is assimilated into amino acids. An improved understanding of nitrogen assimilation is vital if improvements in crop $\mathrm{N}$-use efficiency (NUE) are to be made in order to reduce the need for fertiliser inputs.

The capacity of the oxidative pentose phosphate

*Author for correspondence. pathway (OPPP) in plant tissues is increased during nitrate assimilation, which requires reducing power for nitrate and nitrite reduction (Bowsher et al., 1989). The primary regulated enzyme of the OPPP is glucose-6phosphate dehydrogenase (G6PD), which catalyses the first reaction in the cycle (Esposito et al., 2001) and provides NADPH for nitrate reduction (Savidov et al., 1998). These reactions have been implicated in the provision of reducing agents for a wide range of processes including inorganic $\mathrm{N}$ assimilation (Neuhaus and Emes, 2000), responses to oxidative and field drought stress, and pathogen infection (Chen et al., 2004). G6PD and 6-phosphogluconate dehydrogenase (6PGD) may play important roles in cell division and salt responses in plants (Huang et al., 2003). Glutathione reductase (GR) catalyses the NADPH-dependent reduction of the oxidised form of glutathione to reduced glutathione (GSH; Medici et al., 2004), therefore GR appears to be important during the regeneration of ascorbate and GSH (Tanaka et al., 1994). GR plays a key role in anti-oxidant defense processes and also appears to be related to tolerance to environmental stresses (Tanaka et al., 1994; Chen et al., 2004). Glutathione S-transferase (GST) can protect cells from a wide variety of biotic and abiotic stresses (Zeng et al., 2005; Gong et al., 2005). There have been several studies on the different isoforms of G6PD and GR in leaf tissues, and their relationship with $\mathrm{N}$ metabolism (Wright et al.,1997; 
Savidov et al., 1998; Rios-Gonzales et al., 2002; Medici et al., 2004).

To date, many studies on the introduction of PGPR have focussed on economically important agricultural and wild plants (de Freitas et al., 1997; Sahin et al., 2004; Orhan et al., 2007). However, the effects of PGPR on the activities of anti-oxidant and OPPP cycle enzymes in plants have not been considered. Recently, our studies demonstrated, for the first time, that PGPR could enhance GR, GST, 6PGD and G6PD activities, together with the growth of plants (Çakmakçı et al., 2007a). The beneficial effect of PGPR on plant growth varied, depending on the species, and are strain specific (Şahin et al., 2004).

In this paper, we examine the effects of PGPR on the activities of anti-oxidant (GR and GST) and OPPP (G6PD and 6PGD) enzymes in the leaves of spinach.

\section{MATERIALS AND METHODS}

Bacterial species and strains, isolation, and identification of bacteria

Pseudomonas putida RC06, Bacillus megaterium $\mathrm{RC} 07$, and B. licheniformis $\mathrm{RC} 08$ were isolated from the rhizosphere of wheat and barley (Çakmakçı et al., 2006). Bacillus subtilis RC11 and B. cereus RC18 were initially isolated from the rhizosphere of wild red raspberries (Çakmakçı et al., 2007a) and characterised as PGPR that could promote plant growth, solubilise $\mathrm{P}$, and fix $\mathrm{N}_{2}$. Bacillus subtilis OSU-142 was originally isolated from tomato plants, and B. megaterium M-3 was isolated from pepper (Şahin et al., 2004). Five bacterial strains were first isolated from the rhizosphere of wild red raspberries and identified as Paenibacillus polymyxa RC35, B. mycoides FD07, B. sphaericus RC12, B. pumilus RC19, and Variovorax paradoxus RC21 with similarity indices of $0.729,0.621,0.769,0.488$, and 0.661 , respectively. These indices were based on whole-cell fatty acid methyl ester (FAMEs) analysis (de Freitas et al., 1997) using the Sherlock Microbial Identification System (Version 4.5) and Biolog microplate assays (Biolog Inc., Hayward, CA, USA). All bacterial strains were maintained in nutrient broth (NB) with $15 \%(\mathrm{v} / \mathrm{v})$ glycerol at $-86^{\circ} \mathrm{C}$ for further tests.

\section{Quantification of IAA production}

The PGPR were tested for indole-3-acetic acid (IAA)-like auxin production using the method of Bent et al. (2001). Flasks $(125 \mathrm{ml})$ containing $40 \mathrm{ml}$ half-strength TSB were incubated for $18 \mathrm{~h}$ at $27^{\circ} \mathrm{C}$ on a $100 \mathrm{rpm}$ rotary shaker supplemented with $0,0.1$, or $25 \mu \mathrm{g}$ tryptophan $\mathrm{ml}^{-1}$, then each was inoculated with $1 \mathrm{ml}$ of each PGPR. After incubation for 48, 72, or $168 \mathrm{~h}$, the density of each culture was measured spectrophotometrically at $600 \mathrm{~nm}$. The bacterial cells were removed from the culture medium by centrifugation $(5.500 \times g$ for $10 \mathrm{~min})$. The level of indoles present in the culture fluid was estimated colorimetrically. The concentration of IAA in the culture medium was measured using Salkowski's reagent $[50 \mathrm{ml}$ $35 \%(\mathrm{v} / \mathrm{v}) \mathrm{HClO}_{4}{ }^{+}$containing $1 \mathrm{ml} 0.5 \mathrm{M} \mathrm{FeCl}_{3}$; Gordon and Weber, 1951]. The absorbance was measured at 530 $\mathrm{nm}$ in a Shimadzu UV-1208 spectrophotometer (Tokyo, Japan). Bacterial cells were separated from the supernatant by centrifugation at $10.000 \times g$ for $30 \mathrm{~min}$ at $4^{\circ} \mathrm{C}$. The concentration of IAA in each culture medium was determined by comparison with a standard curve.

\section{Greenhouse experiment and growth conditions}

Spinach (Spinacia oleracea L.) seeds were surfacesterilised in $70 \%(\mathrm{v} / \mathrm{v})$ ethanol for $2 \mathrm{~min}$, and rinsed ten-times in sterile tap water. For this application, pure cultures were grown in $\mathrm{NB}$ at $28^{\circ} \mathrm{C}$ and diluted to a final concentration of $10^{9}$ colony-forming units (cfu) $\mathrm{ml}^{-1}$ in sterile distilled water containing $0.025 \%(\mathrm{v} / \mathrm{v})$ Tween-20. Surface-sterile seeds were inoculated by immersion in the appropriate PGPR suspension (at $10^{9} \mathrm{cfu} \mathrm{ml}^{-1}$ ) for $2 \mathrm{~h}$ on a rotary shaker at $81 \mathrm{rpm}$, air-dried, and sown immediately. The cell densities in the PGPR suspensions were adjusted to a final density of approx. $10^{8} \mathrm{cfu} \mathrm{seed}^{-1}$.

The experimental design consisted of three completely randomised blocks in a factorial arrangement with 13 treatments: twelve PGPR applications, and an uninoculated control. Pots were sterilised with $20 \%$ (v/v) sodium hypochlorite solution and filled with a loamy soil with an organic matter content of $2.1 \%(\mathrm{w} / \mathrm{w})$, a $\mathrm{pH}$ of 6.9 , an available Olsen-P content of $13.4 \mathrm{mg} \mathrm{kg}^{-1}$, and $\mathrm{NH}_{4}{ }^{+}-\mathrm{N}$ and $\mathrm{NO}_{3}{ }^{-}-\mathrm{N}$ contents of 10.1 and $8.9 \mathrm{mg} \mathrm{kg}{ }^{-1}$, respectively. Spinach seeds were sown in plastic pots filled with $5 \mathrm{~kg}$ of field soil. Twelve seeds were sown per pot, at six points (two seeds at each point), then thinned to six uniform plants per pot $10 \mathrm{~d}$ after sowing.

The spinach seedlings were grown in a greenhouse under a $13 \mathrm{~h}$ natural light photoperiod at $18^{\circ}-14^{\circ} \mathrm{C}$, and $65 \%$ relative humidity. Pots were watered to $60 \%$ of their maximum water-holding capacity and were maintained at this moisture content by watering to weight every $2-3$ d. Plants were harvested on day-28 and day-50, after emergence of the seedlings, and separated into shoots and roots. Each root system was washed in deionised water, and its fresh weight (FW) was determined immediately after each harvest. The leaf area of each plant was recorded using an electronic planimeter (Licor-3000; LICOR, Lincoln, NE, USA). Plant materials were then oven-dried at $70^{\circ} \mathrm{C}$ for $72 \mathrm{~h}$, and dry weights (DWs) were determined for all shoots and roots. The macronutrient $(\mathrm{N}, \mathrm{P}, \mathrm{K}, \mathrm{Ca}$ and $\mathrm{Mg}$ ) and micronutrient ( $\mathrm{Fe}, \mathrm{Mn}, \mathrm{Zn}$ and $\mathrm{Cu}$ ) contents of spinach seedlings were determined according to the Association of Official Analytical Chemists (Helrich, 1990).

\section{Extraction of enzymes}

Spinach leaves were harvested, wrapped separately in aluminium foil, then frozen in liquid nitrogen and kept at $-80^{\circ} \mathrm{C}$ prior to use. Two $\mathrm{g}$ of each sample, frozen in liquid nitrogen, was powdered, then added to $10 \mathrm{ml}$ of extraction buffer $(50 \mathrm{mM}$ Tris- $\mathrm{HCl}$, containing $1 \mathrm{mM}$ EDTA and $1 \mathrm{mM}$ DTT, pH 7.5) and mixed. Each mixture was centrifuged at $20,000 \times g$ at $4^{\circ} \mathrm{C}$ for $20 \mathrm{~min}$, and the precipitate was removed. The supernatants were used as crude extracts for the determination of enzyme activities.

\section{Measurements of enzyme activities and protein concentrations}

Glucose-6-phosphate dehydrogenase (G6PD; EC 1.1.1.49) and 6-phosphogluconate dehydrogenase (6PGD; EC 1.1.1.44) activities were determined according to the method of Beutler (1984). The assay 
TABLE I

Production of IAA ( $\mu \mathrm{g} \mathrm{ml}^{-1} O D_{600}$ unit $\left.{ }^{-1}\right)$ by PGPR in the presence of various concentrations of tryptophan

\begin{tabular}{|c|c|c|c|c|}
\hline \multirow{2}{*}{$\begin{array}{l}\text { PGPR } \\
\text { strain* }\end{array}$} & \multicolumn{3}{|c|}{ Tryptophan $\left(\mu \mathrm{g} \mathrm{ml}^{-1}\right)$} & \multirow[b]{2}{*}{ Reference } \\
\hline & 0 & 0.1 & 25 & \\
\hline FD07 & $1.6 \pm 0.4 \mathrm{~g}^{\dagger}$ & $4.3 \pm 0.5 \mathrm{e}$ & $13.4 \pm 1.4 \mathrm{f}$ & This study \\
\hline $\mathrm{RC} 12$ & $5.1 \pm 0.6 \mathrm{~cd}$ & $6.2 \pm 0.7 \mathrm{~d}$ & $21.4 \pm 1.6 \mathrm{de}$ & This study \\
\hline RC19 & $4.9 \pm 0.3 \mathrm{~cd}$ & $6.8 \pm 0.6 \mathrm{~cd}$ & $24.7 \pm 1.3 \mathrm{bc}$ & This study \\
\hline $\mathrm{RC} 21$ & ND & ND & ND & This study \\
\hline M-3 & $3.7 \pm 0.1 \mathrm{e}$ & $4.9 \pm 0.3 \mathrm{e}$ & $18.6 \pm 1.1 \mathrm{e}$ & This study \\
\hline $\mathrm{RC} 35$ & $6.6 \pm 0.9 \mathrm{a}$ & $10.9 \pm 1.1 \mathrm{a}$ & $32.8 \pm 2.7 \mathrm{a}$ & This study \\
\hline $\mathrm{RC} 06$ & $5.7 \pm 0.4 \mathrm{bc}$ & $9.7 \pm 0.8 \mathrm{~b}$ & $26.8 \pm 2.7 \mathrm{~b}$ & Çakmakçı et al. (2007a) \\
\hline $\mathrm{RC} 07$ & $5.6 \pm 0.5 \mathrm{bc}$ & $6.4 \pm 0.4 \mathrm{~d}$ & $25.3 \pm 1.7 \mathrm{bc}$ & Çakmakçı et al. (2007a) \\
\hline $\mathrm{RC} 08$ & $2.6 \pm 0.3 \mathrm{f}$ & $4.9 \pm 0.5 \mathrm{e}$ & $13.6 \pm 1.3 \mathrm{f}$ & Çakmakçı et al. (2007a) \\
\hline $\mathrm{RC} 11$ & $4.3 \pm 0.7 \mathrm{de}$ & $7.9 \pm 0.9 \mathrm{c}$ & $20.4 \pm 1.6 \mathrm{de}$ & Çakmakçı et al. (2007a) \\
\hline RC18 & $1.9 \pm 0.3 \mathrm{fg}$ & $3.7 \pm 0.5 \mathrm{e}$ & $12.4 \pm 1.5 \mathrm{f}$ & Ćakmakçı et al. (2007a) \\
\hline OSU-142 & $6.3 \pm 0.8 \mathrm{ab}$ & $9.6 \pm 0.9 \mathrm{~b}$ & $22.4 \pm 2.1 \mathrm{~cd}$ & Çakmakçı et al. (2007a) \\
\hline
\end{tabular}

*Bacillus mycoides FD07; B. sphaericus RC12; B. pumilus RC19; Variovorax paradoxus RC21; Paenibacillus polymyxa RC35; Pseudomonas putida RC06; B. megaterium RC07; B. licheniformis RC08; B. subtilis RC11; B. cereus RC18; B. megaterium M-3; and B. subtilis OSU-142.

Values are means \pm SE from three separate experiments. Numbers followed by the same lower-case letters in a column are not statistically different according to Duncan's multiple range test $(P \leq 0.05)$. Data are the means of three replicates for IAA production in 48,72 , and $168 \mathrm{~h}$ cultures. ND; not determined.

system contained $0.1 \mathrm{mM}$ Tris- $\mathrm{HCl}$ buffer, $\mathrm{pH} 7.5$, $0.5 \mathrm{mM}$ EDTA, $0.2 \mathrm{mM} \mathrm{NADP}^{+}$, and $0.6 \mathrm{mM}$ G6P for G6PD, or $0.6 \mathrm{mM}$ 6PGA for 6PGD, in a total volume of $1 \mathrm{ml}$. The increase in $\mathrm{A}_{340}$ was monitored over $3 \mathrm{~min}$. One unit of enzyme activity was defined as the reduction of $1 \mu \mathrm{mol} \mathrm{NADP}{ }^{+} \min ^{-1}$ under the assay conditions.

Glutathione reductase (GR; EC 1.8.1.7) activity was assayed according to the method of Carlberg and Mannervik (1985). The assay system contained $0.75 \mathrm{mM}$ Tris-HCl buffer, $\mathrm{pH}$ 7.0, 1 mM EDTA, 1 mM GSSG, and $0.1 \mathrm{mM}$ NADPH, in a total volume of $1 \mathrm{ml}$. The decrease in $A_{340}$ was monitored for $3 \mathrm{~min}$. One unit of enzyme activity was defined as the oxidation of $1 \mu \mathrm{mol}$ NADPH $\min ^{-1}$ under the assay conditions.

Glutathione S-transferase (GST; EC 2.5.1.18) activity was determined as described by Habig and Jacoby (1981). The reaction medium contained $0.1 \mathrm{M}$ potassium phosphate buffer, $\mathrm{pH}$ 6.5, $1.0 \mathrm{mM}$ GSH, $1.0 \mathrm{mM}$ 1chloro-2,4-dinitrobenzene (CDNB), and 1\% (v/v) absolute ethanol, in a total volume of $1.0 \mathrm{ml}$. The reaction was monitored by the increase in $\mathrm{A}_{340}$ for $3 \mathrm{~min}$.

All reactions were initiated by addition of the enzyme

TABLE II

Effect of PGPR on the activities of the anti-oxidant enzymes (GR and GST) and the pentose phosphate oxidative cycle enzymes (G6PD and $6 P G D)$ in spinach leaves

\begin{tabular}{|c|c|c|c|c|}
\hline Treatment & $\begin{array}{l}\text { 6PGD* } \\
\text { (Units mg }{ }^{-1} \\
\text { protein) }\end{array}$ & $\begin{array}{c}\text { G6PD } \\
\text { (Units } \mathrm{mg}^{-1} \\
\text { protein) }\end{array}$ & $\begin{array}{c}\text { GST } \\
\text { (Units mg }{ }^{-1} \\
\text { protein) }\end{array}$ & $\begin{array}{c}\mathrm{GR} \\
\begin{array}{c}\text { (Units mg } \\
\text { protein) }\end{array}\end{array}$ \\
\hline Control & $1.70 \mathrm{ef}^{\dagger}$ & $0.83 \mathrm{de}$ & $2.62 \mathrm{c}$ & $4.26 \mathrm{~g}$ \\
\hline FD07 ${ }^{\#}$ & $1.52 \mathrm{f}$ & $0.99 \mathrm{~b}$ & $2.14 \mathrm{e}$ & $4.17 \mathrm{gh}$ \\
\hline RC12 & $2.40 \mathrm{c}$ & $0.70 \mathrm{f}$ & $2.95 \mathrm{ab}$ & $5.03 \mathrm{~cd}$ \\
\hline RC19 & $1.62 \mathrm{f}$ & $0.58 \mathrm{~g}$ & $1.93 \mathrm{f}$ & $4.56 \mathrm{f}$ \\
\hline $\mathrm{RC} 21$ & $2.39 \mathrm{c}$ & $0.84 \mathrm{de}$ & $2.06 \mathrm{ef}$ & $5.20 \mathrm{c}$ \\
\hline RC35 & $2.26 \mathrm{c}$ & $0.59 \mathrm{~g}$ & $1.71 \mathrm{~g}$ & $4.29 \mathrm{~g}$ \\
\hline RC06 & $3.01 \mathrm{a}$ & $1.21 \mathrm{a}$ & $3.08 \mathrm{a}$ & $4.74 \mathrm{ef}$ \\
\hline $\mathrm{RC} 07$ & $1.84 \mathrm{de}$ & 0.80 ef & $2.17 \mathrm{e}$ & $4.99 \mathrm{~cd}$ \\
\hline RC08 & $1.95 \mathrm{~d}$ & $0.89 \mathrm{~cd}$ & $2.59 \mathrm{c}$ & $4.15 \mathrm{gh}$ \\
\hline RC11 & $2.46 \mathrm{c}$ & $0.99 \mathrm{~b}$ & $3.10 \mathrm{a}$ & $6.00 \mathrm{a}$ \\
\hline RC18 & $2.30 \mathrm{c}$ & $0.88 \mathrm{~d}$ & $2.89 \mathrm{~b}$ & $5.54 \mathrm{~b}$ \\
\hline OSU-142 & 2.74 b & $0.72 \mathrm{f}$ & $2.63 \mathrm{c}$ & $4.92 \mathrm{de}$ \\
\hline M-3 & $1.85 \mathrm{de}$ & $0.96 \mathrm{bc}$ & $2.42 \mathrm{~d}$ & $3.97 \mathrm{~h}$ \\
\hline
\end{tabular}

*G6PD, glucose-6-phosphate dehydrogenase; 6PGD, 6-phosphogluconate dehydrogenase; GR, glutathione reductase; GST, glutathione S-transferase.

${ }^{\dagger}$ Values followed by different lower-case letters in a column were significantly different $(P \leq 0.01)$ using Duncan's multiple range test.

Values are the average from two separate experiments and two harvests (on day-28 and day-50) with three replications ( 3 samples per replicate). $(\mathrm{n}=36)$.

"Bacterial strains are explained in Table I. solution. All enzymatic activities were determined spectrophotometrically at $25^{\circ} \mathrm{C}$ using a Shimadzu 1208 UV spectrophotometer (Kyoto, Japan). One unit of enzyme activity was defined as the formation of $1.0 \mu \mathrm{mol}$ product $\mathrm{min}^{-1}$ (extinction coefficients at $340 \mathrm{~nm}=$ $6.2 \mathrm{mM}^{-1} \mathrm{~cm}^{-1}$ for NADPH, and $9.6 \mathrm{mM}^{-1} \mathrm{~cm}^{-1}$ for the glutathione-2,4-dinitrobenzene conjugate). Protein concentrations were calculated from measurements of the absorbance at $595 \mathrm{~nm}$ according to the method of Bradford (1976) with bovine serum albumin as a standard.

\section{Statistical analysis}

The experiments were performed in a completely randomised design with three replicates. Each replicate consisted of six spinach seedlings at each harvest. The experiment was repeated twice. Enzyme activities were determined on three samples from each replicate. The data were subjected to analysis of variance using STATISTICA 5.1 (Stat Soft Inc., Tulsa, OK, USA) and the means were separated according to Duncan's Multiple Range Test.

\section{RESULTS}

Except for $V$. paradoxus RC21, all species and strains of PGPR used were able to produce plant growthpromoting phytohormones (Table I). The levels of IAA produced by the various PGPR tested, in the presence of $25 \mu \mathrm{g} \mathrm{ml}^{-1}$ tryptophan, ranged from $12.4 \mu \mathrm{g} \mathrm{ml}^{-1}$ for B. cereus RC18, to $33.2 \mu \mathrm{g} \mathrm{ml}^{-1}$ for P. polymyxa $\mathrm{RC} 35$. In the absence of tryptophan, all PGPR produced low levels of IAA (ranging from 1.6 to $6.6 \mu \mathrm{g}$ IAA ml ${ }^{-1}$ culture).

Different rhizobacteria had variable effects (both negative and positive) on the measured enzyme activities and on the FWs and DWs of shoots and roots in spinach (Table II; Table III). Except for PGPR strains FD07, RC07, RC19, and M-3, bacterial inoculation significantly increased 6PGD activities in spinach. Strains FD07, RC06, RC11, and M-3 increased G6PD activity levels. GR and GST activities were greatest with the application of RC11, whereas the highest levels of 6PGD and G6PD activities were determined in treatments with RC06 (Table II). Four and eight of the 12 PGPR strains test selectively increased GST and GR activities in the leaves of spinach plants. 
TABLE III

Effects of inoculation of spinach with plant growth-promoting rhizobacteria (PGPR) on leaf area, whole plant weight, and shoot and root fresh and dry

\begin{tabular}{|c|c|c|c|c|c|c|c|}
\hline Harvest date & Treatment & $\begin{array}{l}\text { Whole plant } \\
\text { weight }\left(\mathrm{g}_{\text { plant }}{ }^{-1}\right)\end{array}$ & $\begin{array}{c}\text { Shoot fresh } \\
\text { weight }\left(\text { g plant }^{-1}\right)\end{array}$ & $\begin{array}{c}\text { Root fresh } \\
\text { weight }\left(\mathrm{g} \text { plant }{ }^{-1}\right)\end{array}$ & $\begin{array}{c}\text { Shoot dry } \\
\text { weight }\left(\mathrm{g} \text { plant }{ }^{-1}\right)\end{array}$ & $\begin{array}{c}\text { Root dry } \\
\text { weight }\left(\mathrm{g} \text { plant }{ }^{-1}\right)\end{array}$ & $\begin{array}{l}\text { Leaf area } \\
\left(\mathrm{cm}^{2} \text { plant }^{-1}\right)\end{array}$ \\
\hline Day-28 & $\begin{array}{l}\text { Control } \\
\text { FD07 } \\
\text { RC12 } \\
\text { RC19 } \\
\text { RC21 } \\
\text { RC35 } \\
\text { RC06 } \\
\text { RC07 } \\
\text { RC08 } \\
\text { RC11 } \\
\text { RC18 } \\
\text { OSU-142 } \\
\text { M-3 }\end{array}$ & $\begin{array}{l}3.43 \mathrm{~h}^{*} \\
3.29 \mathrm{~h} \\
3.83 \mathrm{gh} \\
3.31 \mathrm{~h} \\
3.98 \mathrm{gh} \\
5.04 \mathrm{~g} \\
4.80 \mathrm{~g} \\
4.57 \mathrm{~g} \\
4.35 \mathrm{gh} \\
3.98 \mathrm{gh} \\
4.07 \mathrm{gh} \\
4.60 \mathrm{~g} \\
4.00 \mathrm{gh}\end{array}$ & $\begin{array}{l}3.06 \mathrm{~g} \\
2.96 \mathrm{~g} \\
3.47 \mathrm{fg} \\
2.97 \mathrm{~g} \\
3.67 \mathrm{fg} \\
4.56 \mathrm{f} \\
4.35 \mathrm{f} \\
4.19 \mathrm{f} \\
3.89 \mathrm{fg} \\
3.63 \mathrm{fg} \\
3.60 \mathrm{fg} \\
4.19 \mathrm{f} \\
3.54 \mathrm{fg}\end{array}$ & $\begin{array}{l}0.37 \mathrm{fgh} \\
0.33 \mathrm{~h} \\
0.36 \mathrm{fgh} \\
0.34 \mathrm{gh} \\
0.32 \mathrm{~h} \\
0.47 \mathrm{f} \\
0.45 \mathrm{fg} \\
0.38 \mathrm{fgh} \\
0.46 \mathrm{fg} \\
0.35 \mathrm{gh} \\
0.46 \mathrm{fg} \\
0.42 \mathrm{fgh} \\
0.46 \mathrm{fg}\end{array}$ & $\begin{array}{l}0.40 \mathrm{~h} \\
0.38 \mathrm{~h} \\
0.44 \mathrm{gh} \\
0.40 \mathrm{~h} \\
0.47 \mathrm{gh} \\
0.55 \mathrm{~g} \\
0.53 \mathrm{gh} \\
0.56 \mathrm{~g} \\
0.51 \mathrm{gh} \\
0.46 \mathrm{gh} \\
0.43 \mathrm{gh} \\
0.50 \mathrm{gh} \\
0.50 \mathrm{gh}\end{array}$ & $\begin{array}{l}0.08 \\
0.07 \\
0.09 \\
0.08 \\
0.06 \\
0.11 \\
0.10 \\
0.08 \\
0.11 \\
0.09 \\
0.11 \\
0.10 \\
0.11\end{array}$ & $\begin{array}{l}66 \mathrm{~g} \\
63 \mathrm{~g} \\
72 \mathrm{fg} \\
64 \mathrm{~g} \\
76 \mathrm{fg} \\
95 \mathrm{ef} \\
87 \mathrm{f} \\
85 \mathrm{fg} \\
81 \mathrm{fg} \\
75 \mathrm{fg} \\
75 \mathrm{fg} \\
91 \mathrm{f} \\
76 \mathrm{fg}\end{array}$ \\
\hline Day-50 & $\begin{array}{l}\text { Control } \\
\text { FD07 } \\
\text { RC12 } \\
\text { RC19 } \\
\text { RC21 } \\
\text { RC35 } \\
\text { RC06 } \\
\text { RC07 } \\
\text { RC08 } \\
\text { RC11 } \\
\text { RC18 } \\
\text { OSU-142 } \\
\text { M-3 }\end{array}$ & $\begin{array}{l}15.21 \mathrm{f} \\
14.94 \mathrm{f} \\
17.18 \mathrm{e} \\
15.17 \mathrm{f} \\
18.86 \mathrm{bcd} \\
20.47 \mathrm{a} \\
20.41 \mathrm{a} \\
18.98 \mathrm{bcd} \\
18.13 \mathrm{de} \\
19.44 \mathrm{abc} \\
19.96 \mathrm{a} \\
19.36 \mathrm{abc} \\
18.77 \mathrm{~cd}\end{array}$ & $\begin{array}{l}14.12 \mathrm{e} \\
13.89 \mathrm{e} \\
16.01 \mathrm{~d} \\
14.07 \mathrm{e} \\
17.69 \mathrm{bc} \\
19.07 \mathrm{a} \\
19.09 \mathrm{a} \\
17.62 \mathrm{bc} \\
16.97 \mathrm{~cd} \\
18.15 \mathrm{ab} \\
18.52 \mathrm{ab} \\
18.04 \mathrm{abc} \\
17.41 \mathrm{bc}\end{array}$ & $\begin{array}{l}1.09 \mathrm{de} \\
1.05 \mathrm{e} \\
1.17 \mathrm{~d} \\
1.11 \mathrm{de} \\
1.17 \mathrm{~d} \\
1.40 \mathrm{ab} \\
1.33 \mathrm{abc} \\
1.36 \mathrm{abc} \\
1.16 \mathrm{de} \\
1.29 \mathrm{c} \\
1.44 \mathrm{a} \\
1.32 \mathrm{bc} \\
1.36 \mathrm{abc}\end{array}$ & $\begin{array}{l}1.89 \mathrm{f} \\
1.82 \mathrm{f} \\
2.05 \mathrm{e} \\
1.85 \mathrm{f} \\
2.26 \mathrm{bcd} \\
2.40 \mathrm{ab} \\
2.42 \mathrm{a} \\
2.35 \mathrm{ab} \\
2.18 \mathrm{~d} \\
2.39 \mathrm{ab} \\
2.36 \mathrm{ab} \\
2.42 \mathrm{a} \\
2.22 \mathrm{~cd}\end{array}$ & $\begin{array}{l}0.44 \\
0.45 \\
0.47 \\
0.43 \\
0.47 \\
0.59 \\
0.62 \\
0.52 \\
0.49 \\
0.49 \\
0.60 \\
0.46 \\
0.57\end{array}$ & $\begin{array}{l}305 \mathrm{e} \\
288 \mathrm{e} \\
333 \mathrm{~d} \\
297 \mathrm{e} \\
368 \mathrm{bc} \\
390 \mathrm{ab} \\
385 \mathrm{ab} \\
352 \mathrm{~cd} \\
353 \mathrm{~cd} \\
377 \mathrm{ab} \\
380 \mathrm{ab} \\
390 \mathrm{ab} \\
351 \mathrm{~cd}\end{array}$ \\
\hline Average $^{\#}$ & $\begin{array}{l}\text { Control } \\
\text { FD07 } \\
\text { RC12 } \\
\text { RC19 } \\
\text { RC21 } \\
\text { RC35 } \\
\text { RC06 } \\
\text { RC07 } \\
\text { RC08 } \\
\text { RC11 } \\
\text { RC18 } \\
\text { OSU-142 } \\
\text { M-3 }\end{array}$ & $\begin{array}{c}9.32 \mathrm{~d} \\
9.12 \mathrm{~d} \\
10.51 \mathrm{c} \\
9.24 \mathrm{~d} \\
11.42 \mathrm{~b} \\
12.75 \mathrm{a} \\
12.60 \mathrm{a} \\
11.78 \mathrm{~b} \\
11.24 \mathrm{~b} \\
11.71 \mathrm{~b} \\
12.01 \mathrm{ab} \\
11.98 \mathrm{ab} \\
11.38 \mathrm{~b}\end{array}$ & $\begin{array}{l}8.59 \mathrm{e} \\
8.43 \mathrm{e} \\
9.74 \mathrm{~d} \\
8.52 \mathrm{e} \\
10.68 \mathrm{c} \\
11.82 \mathrm{a} \\
11.72 \mathrm{ab} \\
10.90 \mathrm{c} \\
10.43 \mathrm{~cd} \\
10.89 \mathrm{c} \\
11.06 \mathrm{bc} \\
11.11 \mathrm{abc} \\
10.48 \mathrm{~cd}\end{array}$ & $\begin{array}{l}0.73 \mathrm{ef} \\
0.69 \mathrm{f} \\
0.77 \mathrm{def} \\
0.72 \mathrm{f} \\
0.74 \mathrm{def} \\
0.93 \mathrm{ab} \\
0.89 \mathrm{abc} \\
0.87 \mathrm{abc} \\
0.81 \mathrm{cde} \\
0.82 \mathrm{~cd} \\
0.95 \mathrm{a} \\
0.87 \mathrm{bc} \\
0.91 \mathrm{ab}\end{array}$ & $\begin{array}{l}1.14 \mathrm{e} \\
1.10 \mathrm{e} \\
1.25 \mathrm{~d} \\
1.12 \mathrm{e} \\
1.36 \mathrm{bc} \\
1.48 \mathrm{a} \\
1.47 \mathrm{a} \\
1.45 \mathrm{ab} \\
1.35 \mathrm{c} \\
1.43 \mathrm{abc} \\
1.40 \mathrm{abc} \\
1.46 \mathrm{a} \\
1.36 \mathrm{bc}\end{array}$ & $\begin{array}{l}0.26 \mathrm{c} \\
0.25 \mathrm{c} \\
0.28 \mathrm{~b} \\
0.26 \mathrm{c} \\
0.26 \mathrm{c} \\
0.35 \mathrm{a} \\
0.36 \mathrm{a} \\
0.30 \mathrm{~b} \\
0.30 \mathrm{~b} \\
0.29 \mathrm{~b} \\
0.36 \mathrm{a} \\
0.28 \mathrm{~b} \\
0.31 \mathrm{~b}\end{array}$ & $\begin{array}{l}186 \mathrm{f} \\
175 \mathrm{f} \\
203 \mathrm{e} \\
180 \mathrm{f} \\
222 \mathrm{~cd} \\
242 \mathrm{a} \\
236 \mathrm{abc} \\
218 \mathrm{~d} \\
217 \mathrm{de} \\
226 \mathrm{bcd} \\
228 \mathrm{abcd} \\
240 \mathrm{ab} \\
213 \mathrm{de}\end{array}$ \\
\hline
\end{tabular}

"Values followed by different lower-case letters in a column were significantly different $(P \leq 0.05)$ using Duncan's multiple range test.

†alues are the averages from the two experiments with three replications.

\#Average of 28- and 50-day harvests.

Apart from FD07 and RC19, the ten remaining PGPR strains tested significantly increased whole plant weight (WPW), shoot fresh weight (SFW) and leaf area (LA) in spinach plants compared to the controls (Table III). The maximum SFW and shoot DWs in spinach were found after RC35 inoculation, followed by RC06 and OSU-142. The highest root FWs and DWs were observed after RC18 inoculation, followed by RC35 and RC06 treatments. In general, inoculation with RC35, RC06, RC18, or OSU-142 resulted in higher yields in terms of WPW and LA (Table III).
Four of the PGPR strains (FD07, RC12, RC19, and RC07) did not change the $\mathrm{N}$ content of spinach plants. On the other hand, the other eight strains significantly increased $\mathrm{N}$ concentrations in spinach. In addition, six of the strains (RC35, RC06, RC07, RC08, RC11, and $\mathrm{RC} 21)$ significantly increased the $\mathrm{P}$ content of spinach plants, but not $\mathrm{K}, \mathrm{Ca}, \mathrm{Mn}, \mathrm{Zn}$ and $\mathrm{Fe}$ concentrations (Table IV). The maximum $\mathrm{N}$ concentration in spinach leaves was found after RC11 treatment, followed by RC35, RC06, and OSU-142 treatments. In the case of increasing P concentrations, RC07 and RC35 were the

TABLE IV

Effect of plant growth-promoting rhizobacteria (PGPR) on macro- and micro-nutrient concentrations in spinach leaves

\begin{tabular}{|c|c|c|c|c|c|c|c|c|c|}
\hline \multirow[b]{2}{*}{ Treatment } & \multicolumn{5}{|c|}{ Macro-nutrient $\left(\mathrm{g} \mathrm{kg}^{-1} \mathrm{DW}\right)$} & \multicolumn{4}{|c|}{ Micro-nutrient ( $\left.\mathrm{mg} \mathrm{kg}^{-1} \mathrm{DW}\right)$} \\
\hline & $\mathrm{N}$ & $\mathrm{P}$ & $\mathrm{K}$ & $\mathrm{Ca}$ & $\mathrm{Mg}$ & $\mathrm{Fe}$ & $\mathrm{Mn}$ & $\mathrm{Zn}$ & $\mathrm{Cu}$ \\
\hline Control & $18.9 \mathrm{c}^{*}$ & $5.5 \mathrm{c}$ & $6.9 \mathrm{a}-\mathrm{c}$ & $10.4 \mathrm{a}$ & $7.6 \mathrm{bc}$ & $101 \mathrm{a}$ & $112 \mathrm{a}$ & $77 \mathrm{a}$ & $10.1 \mathrm{c}$ \\
\hline FD07 & $19.0 \mathrm{c}$ & $5.2 \mathrm{c}$ & $6.7 \mathrm{bc}$ & $10.6 \mathrm{a}$ & $7.5 \mathrm{c}$ & $104 \mathrm{a}$ & $113 \mathrm{a}$ & $74 \mathrm{a}$ & $10.1 \mathrm{c}$ \\
\hline $\mathrm{RC} 12$ & $18.5 \mathrm{c}$ & $5.1 \mathrm{c}$ & $6.9 \mathrm{a}-\mathrm{c}$ & $10.4 \mathrm{a}$ & $7.8 \mathrm{bc}$ & $102 \mathrm{a}$ & $110 \mathrm{a}$ & $73 \mathrm{a}$ & $10.3 \mathrm{c}$ \\
\hline RC19 & $18.1 \mathrm{c}$ & $5.1 \mathrm{c}$ & $7.0 \mathrm{a}-\mathrm{c}$ & $9.9 \mathrm{a}$ & $8.0 \mathrm{ac}$ & $101 \mathrm{a}$ & $113 \mathrm{a}$ & $78 \mathrm{a}$ & $10.6 \mathrm{bc}$ \\
\hline $\mathrm{RC} 21$ & $20.9 \mathrm{~b}$ & $6.0 \mathrm{~b}$ & $7.2 \mathrm{a}$ & $10.2 \mathrm{a}$ & $8.6 \mathrm{a}$ & $99 \mathrm{a}$ & $105 \mathrm{a}$ & $77 \mathrm{a}$ & $10.5 \mathrm{bc}$ \\
\hline $\mathrm{RC} 35$ & $24.0 \mathrm{a}$ & $6.9 \mathrm{a}$ & $7.3 \mathrm{a}$ & $10.0 \mathrm{a}$ & $8.3 \mathrm{ab}$ & $108 \mathrm{a}$ & $104 \mathrm{a}$ & $72 \mathrm{a}$ & $11.0 \mathrm{ab}$ \\
\hline RC06 & $24.0 \mathrm{a}$ & $6.0 \mathrm{~b}$ & $7.0 \mathrm{a}-\mathrm{c}$ & $10.1 \mathrm{a}$ & $8.5 \mathrm{a}$ & $103 \mathrm{a}$ & $107 \mathrm{a}$ & $72 \mathrm{a}$ & $10.4 \mathrm{c}$ \\
\hline $\mathrm{RC} 07$ & $18.6 \mathrm{c}$ & $6.7 \mathrm{a}$ & $7.0 \mathrm{a}-\mathrm{c}$ & $10.3 \mathrm{a}$ & $8.5 \mathrm{a}$ & $104 \mathrm{a}$ & $113 \mathrm{a}$ & $76 \mathrm{a}$ & $11.2 \mathrm{a}$ \\
\hline $\mathrm{RC} 08$ & $21.1 \mathrm{~b}$ & $6.2 \mathrm{~b}$ & $6.7 \mathrm{bc}$ & $9.9 \mathrm{a}$ & $7.9 \mathrm{ac}$ & $102 \mathrm{a}$ & $105 \mathrm{a}$ & $76 \mathrm{a}$ & $11.6 \mathrm{a}$ \\
\hline RC11 & $24.1 \mathrm{a}$ & $6.1 \mathrm{~b}$ & $6.9 \mathrm{a}-\mathrm{c}$ & $10.5 \mathrm{a}$ & $7.5 \mathrm{c}$ & $107 \mathrm{a}$ & $111 \mathrm{a}$ & $73 \mathrm{a}$ & $11.5 \mathrm{a}$ \\
\hline $\mathrm{RC} 18$ & $20.6 \mathrm{~b}$ & $5.4 \mathrm{c}$ & $6.8 \mathrm{bc}$ & $9.8 \mathrm{a}$ & $8.6 \mathrm{a}$ & $102 \mathrm{a}$ & $105 \mathrm{a}$ & $77 \mathrm{a}$ & $11.2 \mathrm{a}$ \\
\hline OSU-142 & $23.9 \mathrm{a}$ & $5.4 \mathrm{c}$ & $7.2 \mathrm{ab}$ & $10.5 \mathrm{a}$ & $8.2 \mathrm{a}-\mathrm{c}$ & $107 \mathrm{a}$ & $106 \mathrm{a}$ & $74 \mathrm{a}$ & $10.6 \mathrm{bc}$ \\
\hline M-3 & $20.2 \mathrm{~b}$ & $5.5 \mathrm{c}$ & $7.0 \mathrm{a}-\mathrm{c}$ & $10.1 \mathrm{a}$ & $7.7 \mathrm{bc}$ & $104 \mathrm{a}$ & $105 \mathrm{a}$ & $74 \mathrm{a}$ & $10.5 \mathrm{c}$ \\
\hline
\end{tabular}

"Mean values in the same column followed by the same lower-case letters did not differ significantly by Duncan's multiple range test at $P \leq 0.05$. 
most effective, followed by $\mathrm{RC} 08, \mathrm{RC} 11, \mathrm{RC} 06$ and $\mathrm{RC} 21$.

\section{DISCUSSION}

The present study showed that 11 of the PGPR strains tested were able to produce and secrete IAA under in vitro conditions. Paenibacillus polymyxa RC35 was determined to be the best in terms of IAA production, and all plant yield parameters, compared to the other treatments. A positive relationship between the amount of IAA secreted and plant yield values was also observed for some of the other PGPR treatments such as RC06, RC07, and OSU-142 (Table I; Table III). This result confirmed the evidence in previous studies suggesting that the production of hormones is one of the mechanisms by which PGPR stimulate plant growth (Steenhoudt and Vanderleyden, 2000; Çakmakçı et al., 2007b). In contrast, RC18 was one of the lowest IAA producing PGPR strains, but good for yield parameters (Table I; Table III). This observation suggests that production of IAA is not the only PGPR trait responsible for the enhancement of spinach growth. As reported previously, the effect of PGPR is a complex process, and depends on the bacterial strain and population, on the plant-bacterial strain combination, the plant genotype, the growth parameters evaluated, and environmental conditions (Şahin et al., 2004; Çakmakçı et al., 2006). In addition, our results showed that some PGPR (e.g., RC35, RC06, RC11, OSU-142, RC21, RC07, RC18, and M3) treatments significantly increased $\mathrm{N}$ and/or $\mathrm{P}$ uptake in a similar way to their effects on increasing the growth and yield parameters of spinach plants.
Under greenhouse conditions, our previously isolated IAA-producing and P-solubilising PGPR strain, RC11, caused the maximum enhancement in GR and GST activities in spinach, while the $\mathrm{N}_{2}$-fixing and IAA-producing strain RC06 was the most effective promoter of G6PD and 6PGD activities. This provides clear evidence for increased GR activity induced by PGPR inoculation in spinach leaves. Medici et al. (2004) showed, in three plant species, that GR activity increased at high levels of $\mathrm{N}$ supply compared with low $\mathrm{N}$. Ammonium-fed plants showed higher GR activities in maize and sunflower leaves, with the highest GST activity in maize (Rios-Gonzalez et al., 2002). Other studies have indicated that G6PD and 6PGD activities are higher in roots supplied with $\mathrm{NO}_{3}^{-}$(Bowsher et al., 1989; Wright et al., 1997) and these activities depend on changes in plant growth and development (Esposito et al., 2001).

The observed changes in enzyme activities appeared to be triggered by the PGPR strain selected. Since PGPR inoculation caused a differential increase in leaf 6PGD activity, as well as activation of other plant enzymes, this may indicate that activation of these enzymes in spinach leaves would be differentially affected by different PGPR strain. Thus, the growth and yield parameters of spinach seedlings could be enhanced by PGPR treatment due to increases in the activities of enzymes which have an important role in nitrate assimilation as well as in water and nutrient use efficiency. Additional studies are required to confirm the effects of PGPR strains on the different enzyme activities responsible for plant nutrient uptake in other plant species under different conditions.

\section{REFERENCES}

Bent, E., Tuzun, S., Chanway, C. P. and Enebak, S. (2001). Alterations in plant growth and in root hormone levels of lodgepole pines inoculated with rhizobacteria. Canadian Journal of Microbiology, 47, 793-800.

Beutler, E. (1984). Red Cell Metabolism. A Manual of Biochemical Methods. 3rd Edition, Grune Stratton Inc., Orlando, FL, USA. 68-73.

Bowsher, C. G., Hucklesby, D. P. and Emes, M. J. (1989). Nitrite reduction and carbohydrate metabolism in plastids purified from roots of Pisum sativum L. Planta, 177, 359-366.

BRADFORD, M.M. (1976). A rapid and sensitive method for the quantitation of microgram quantities of protein utilizing the principle of protein-dye binding. Analytical Biochemistry, 72, 248-254.

ÇAKMAKÇI, R., DönMEZ, F., AYdin, A. and ŞAHIN, F. (2006). Growth promotion of plants by plant growth-promoting rhizobacteria under greenhouse and two different field soil conditions. Soil Biology and Biochemistry, 38, 1482-1487.

ÇAKmakÇI, R., Erat, M., ERdogan, Ü. and Dönmez, F. (2007a). The influence of plant growth-promoting rhizobacteria on growth and enzyme activities in wheat and spinach plants. Journal of Plant Nutrition and Soil Science, 170, 288-295.

ÇAKMAKÇI, R., DönMEZ, M. F. and ERdoGan, Ü. (2007b). The effect of plant growth promoting rhizobacteria on barley seedling growth, nutrient uptake, some soil properties, and bacterial counts. Turkish Journal of Agriculture and Forestry, 31, 189-199.

CARlBerg, I. and MANNERVIK, B. (1985). Glutathione reductase. In: Methods in Enzymology. (Meister, A., Ed.). Academic Press, Orlando, FL, USA. 113, 484-490.
Chen, K. M., Gong, H. J., Chen, G. C., WAng, S. M. and Zhang, C. L. (2004.) Gradual drought under field conditions influences the glutathione metabolism, redox balance and energy supply in spring wheat. Journal of Plant Growth Regulation, 23, 20-28.

De Freitas, J. R., Banerjee, M. R. and Germida, J. J. (1997). Phosphate-solubilizing rhizobacteria enhance the growth and yield but not phosphorus uptake of canola (Brassica napus L.). Biology and Fertility of Soils, 24, 358-364.

Dobbelaere, S., Vanderleyden, J. and OKon, Y. (2003). Plant growth-promoting effects of diazotrophs in the rhizosphere. Critical Reviews in Plant Sciences, 22, 107-149.

Esposito, S., Massaro, G., Vona, V., Di Martino Rigano, V., CARFagna, S. and Rigano, C. (2001). Ammonium induction of a novel isoform of glucose-6P dehydrogenase in barley roots. Physiologia Plantarum, 113, 469-476.

Gong, H. B., JiaO, Y. X., Hu, W. W. and Pua, E. C. (2005). Expression of glutathione-S-transferase and its role in plant growth and development in vivo and shoot morphogenesis in vitro. Plant Molecular Biology, 57, 53-66.

Gordon, S. A., and WeBER, R. P. (1951). Colorimetric estimation of indoleacetic acid. Plant Physiology, 26, 192-195.

GÜLSER, F. (2005). Effects of ammonium sulphate and urea on $\mathrm{NO}_{3}{ }^{-}$ and $\mathrm{NO}_{2}^{-}$accumulation, nutrient contents and yield criteria in spinach. Scientia Horticulturae, 106, 330-340.

HABIG, W. H. and JAKOBY, W. B. (1981). Assays for differentiation of glutathione S-transferases. Methods in Enzymology, 77, 398-405. 
HELRICH, K. (1990). Official Methods of Analysis of the Association of Official Analytical Chemists. Association of Official Analytical Chemists (AOAC). 15th Edition. Volume 1. Arlington, VA, USA. 684 pp.

HuAnG, J., Zhang, H. S., WANG, J. F. and YANG, J. S. (2003). Molecular cloning and characterization of rice 6-phosphogluconate dehydrogenase gene that is up-regulated by salt stress. Molecular Biology Reports, 30, 223-227.

Medici, L. O., Azevedo, R. A., SMith, R. J. and Lea, P. J. (2004). The influence of nitrogen supply on antioxidant enzymes in plant roots. Functional Plant Biology, 31, 1-9.

Neunaus, H. E. and Emes, M. J. (2000). Nonphotosynthetic metabolism in plastids. Annual Review of Plant Physiology and Plant Molecular Biology, 51, 111-140.

Orhan, E., EsitKen, A., ERCISLI, S. and SAHIN, F. (2007). Effects of indole-3-butyric acid (IBA), bacteria and radicle tip-cutting on lateral root induction in Pistacia vera. Journal of Horticultural Science \& Biotechnology, 82, 2-4.

Rios-GonZalez, K., ERdeI, L. and LiPs, S. H. (2002). The activity of antioxidant enzymes in maize and sunflower seedlings as affected by salinity and different nitrogen sources. Plant Science, 162, 923-930.
SAHIN, F., CAKMAKCI, R. and KANTAR, F. (2004). Sugar beet and barley yields in relation to inoculation with $\mathrm{N}_{2}$-fixing and phosphate solubilizing bacteria. Plant and Soil, 265, 123-129.

SAvidov, N. A., Alikulov, Z. A. and LiPS, S.H. (1998). Identification of an endogenous NADPH-regenerating system coupled to nitrate reduction in vitro in plant and fungal crude extracts. Plant Science, 133, 33-45.

Steenhoudt, O. and Vanderleyden, J. (2000). Azospirillum, a free-living nitrogen-fixing bacterium closely associated with grasses: genetic, biochemical and ecological aspects. FEMS Microbiology Reviews, 24, 487-506.

Tanaka, K., Sano, T., Ishizuka, K., Kitta, K. and Kawamura, Y. (1994). Comparison of properties of leaf and root glutathione reductases from spinach. Physiologia Plantarum, 91, 353-358.

Wright, D. P., HupPe, H. C. and Turpin, D. H. (1997). In vivo and in vitro studies of glucose-6-phosphate dehydrogenase from barley root plastids in relation to reductant supply for $\mathrm{NO}_{2}$ assimilation. Plant Physiology, 114, 1413-1419.

Zeng, Q. Y., LU, H. and WANG, X. R. (2005). Molecular characterization of a glutathione transferase from Pinus tabulaeformis (Pinaceae). Biochimie, 87, 445-455. 